Soner Doğan

Education Faculty of Sivas Cumhuriyet University

Sivas, Turkey
Original scientific paper

UDC: 37.018 .38

DOI: $10.17810 / 2015.104$

\title{
THE CHANGING FACE OF ORGANIZATIONAL COMMUNICATION: SCHOOL WHATSAPP GROUPS
}

\begin{abstract}
The aim of this study is to analyze the school WhatsApp groups, which are used as organizational communication tools at schools with regard to the opinions of teachers and administrators. In this context, the school WhatsApp groups were evaluated in teacher-parent WhatsApp groups. This is qualitative research and it is structured according to phenomenological design. The study group consists of 110 teachers and 51 administrators working at 30 schools located in the city center of Sivas. The data were collected using a questionnaire developed by the researcher and consisting of open-ended questions. The collected data were analyzed through content analysis method and presented under six themes. According to the findings of the research, both teachers and administrators expressed mostly negative opinions on teacher-parent WhatsApp group. According to the opinions of the participants, while school WhatsApp groups provide an advantage in terms of instant communication, saving stationary and time, quick decision making and implementation, improving internal relations, they are also disadvantaging in regard to misuse, conflicts due to misunderstandings, engaging on out-of-hours, harming the school climate and culture and minimizing face-to-face communication. In this context, the participants made suggestions such as determining group rules and ensuring observance of them, informing group members regarding the aims of the group, only group admins texting the group and not abandoning face-to-face communication.
\end{abstract}

Keywords: organizational communication, school whatsapp groups, teacher-parent whatsapp groups, social media.

\section{INTRODUCTION}

Communication is an indispensable tool for maintaining healthy relationships between people. New communication tools began to be used due to technological developments. New communication tools have deeply affected both the private and professional lifestyles of individuals. Rapidly spreading social media craze, especially with internet services, holds all aspect of human life captive, so to say. Days start with social media and end with social media. Social media drives people away from reality, drags them into a new field of communication that cannot be controlled or supervised. In this new field of communication, people's behaviours, attitudes and habits have been changing and taking a new form. As a natural process, the reflections of this change have transformed from the individual dimension to organizational dimension. Now, organizations are also restructuring in new communication fields and they change their organizational communication behaviours. 
Individuals who recognize the outside world through communication, who are organized to fulfill their needs, and who use organizational communication channels for continued existence of the organization that they are a part of, have formed organizational communication mechanisms (Timmerman and Salem, 2017; Mumby and Kuhn, 2018). Thanks to the communication network which is one of the key elements of the organization (Taymaz, 2009) the effectiveness, efficiency, innovativeness and success of the organization are provided (Ilgar, 2005; Ozdemir, 2000), the planning needed for the organization to reach its goals is actualized (Ibrahim and Mahmoud, 2017) and workers' organizational commitment level is improved (Genç, 2009). If organizational communication network is not established sturdily, having difficulties within the organization will be inevitable as stated by Bursalioglu (2005).

School organization is a structure that represents all segments of the society in terms of social dynamics and that mostly stands out with the presence and abundance of communication networks contained within itself. Gathering the social capital that school partners have through communication channels and using them play an important role in the success and improvement of school organization. Arlestig (2007) effectiveness of the school is directly related to the network of relationships established within the school. Bynum (2011) healthy and safe communication mechanisms established in the school provide a happy, efficient and quality working environment. Celep (1992) Teachers and administrators, by solving existing problems through establishing two-way communication within the school, make educating creative, productive students who have democratic values possible. On the other hand, according to Karsli (2006), it is not possible to steer school partners to common goals and set common values within the school without establishing a healthy communication mechanism in the school.

Nowadays, in parallel with technological developments, the way of communication has been changing rapidly. In particular, the increase in internet usage rates and the emerging social media world which has developed due to emerging demands have led to the formation of a new communication field. People communicate without the limitations of place and time concepts through social media and make sharings by creating various groups and platforms (Cox and McLeod, 2014; Murray, 2008; Alakurt and Yilmaz, 2016; Çemrek, Baykuş and Ozaydın, 2014). The internet has now become a habitat where people spend their time and virtual communities, which are a new type of community, have emerged (Biçer, 2014: 59). The use of social media has become a phenomenon over time (Lenhart, et al., 2010; Koseogu, 2012) and conducted researches have shown that the use of the Internet and especially social media continues to expand to include individuals and institutions in all areas (Lester, 2012; Boyd and Ellison, 2007; Thompson, 2009; Koseoglu and Al, 2013; Şener and Samur, 2013; Alican, 2013; Oyman, 2016).

The conscious use of social media facilitates learning and interpersonal interaction, thus providing serious opportunities for education within this context (Liu, 2010; Vander Broek, Puiszis and Brown, 2009; Dabbagh and Kitsantas, 2011; Ekici, 2012; Tanriverdi and Sagir, 2014; Cemaloglu, Bicak, 2015; Kocadere and Ashkar, 2013). While it is possible to communicate instantaneously, reach information quickly, create a platform for discussion and become transparent through social media, it should also be remembered that there is an uncontrolled area which can be exploited by malicious people (Eren and Aydin, 2014). In this context, social 
media may benefit individuals or cause harm according to how they use it (Wasserman and Zwebner, 2017; Eren and Aydin, 2014; Greenhow and Robelia, 2009).

Considering that social media is not only an individual but also an organizational area of use, it can be said that it affects the communication within the organization in a positive or negative way. According to Solmaz, Tekin, Herzem, Demir (2013), the internal use of social media is increasing rapidly. Institutions use social media networks to make quicker decisions and reach their targets. According to Ozdemir and Erdem (2016), social media, which emerged as an alternative to face-to-face communication, should be examined in terms of organizational communication processes as a structure that responds to organizational communication needs. Şengoz and Eroglu (2017) emphasize that organization employees should use social media carefully in order to ensure that the use of social media is sustainable and does not harm the institution.

Today, Facebook, WhatsApp, Instagram, Twitter are among the most used social media tools. These social media tools are used frequently in the process of establishing both individual and internal communication. However, recently, (https://nedir.kim/whatsapp/) WhatsApp social media tool used by more than a billion people in 180 countries can be said to come to the forefront especially with WhatsApp groups established within the organization. The advantages of internally created WhatsApp groups such as instant communication, saving time and stationery, quick decision making and implementation come to the fore. However, many misunderstandings occur in the correspondences exchanged within WhatsApp groups, therefore, serious problems and conflicts are observed to occur. It can be said that WhatsApp groups make business life easier on one hand and harder on the other hand.

Schools are among the institutions in which WhatsApp social media tool is most commonly used. Considering that hundreds of students are all together and a new situation appears at any moment in the school environment, instant communication gains importance. It can be said that school WhatsApp groups meet this need. School WhatsApp groups usually occur in two different ways: among the internal staff and among the teacher and parents. WhatsApp groups established among the staff of the institution are oriented towards internal operations, while teacher-parent WhatsApp groups are mostly used for student follow-up and development. Both WhatsApp groups can provide a lot of benefits when used consciously and correctly, whereas they can damage the institution seriously when used incorrectly. In this respect, it is important to analyze the effects of the usage of school WhatsApp groups on the functioning of the school organization.

In Turkey, researches made associating WhatsApp social media tool with the education sector are limited and specific to foreign language education and perception of WhatsApp use (Yaman, 2016; Sahan, Çoban and Razi, 2016; Pinar and Pinar, 2017; Sebetci, Topal, Hanayliand Donuk, 2018).However, in the international literature, a large number of studies have been conducted by associating WhatsApp social media tool with different areas of the education sector (Bouhnik, Deshen and Gan, 2014; Jafari and Chalak 2016; Bansal and Joshi, 2014; Farmer, Liu and Dotson, 2016; Gon and Rawekar, 2017; Rosenberg and Asterhan, 2018). The aim of this study is to analyze the school WhatsApp groups, between the teacher and parents- with regard to the opinions of teachers and administrators. We did not encounter any research on this subject in Turkey, other than research aimed at WhatsApp group communication of preschool teachers with parents made by Balci and Şahin (2018). In the international literature, there are few research on WhatsApp groups established between teachers and 
parents (Wasserman and Zwebner, 2017; Addi-Raccah and Yemini, 2018; Mayangsari and Aprianti, 2017), established among teachers (Tarisayi and Manhibi, 2017; Cansoy, 2017) andestablished between the teacher-student (Rosenberg and Asterhan 2018; Hershkovitz, Abu Elhija and Zedan, 2019; Bouhnik and Deshen, 2014). The research is important with its findings and practical suggestions and contributes to the literature.

\section{METHOD}

In the method section, information on the research model, study group, data collection tool and data analysis are presented.

\section{Research Model}

In this study, a phenomenological design which is one of the qualitative research methods is used. Phenomenology is qualitative research design that enables individuals to express the existing phenomena in their environment through their own subjective perspectives based on their experiences. In this context, the relationship of the individual's experiences with the phenomenon is emphasized and the common meanings that arise from this relationship are used to analyze the research data (Kocabiyik, 2015). In phenomenology researches, there is an effort to thoroughly understand the phenomena that are close to individuals but not fully explained (Yildirim and Simsek, 2011). School WhatsApp groups are frequently used among school partners with the development and widespread use of social communication tools. These groups changed the way of communication between school partners over time and led to the formation of a new communication field. This new communication field formed with the school WhatsApp groups has brought along both positive and negative results and has emerged as an unpredictable phenomenon. In this study, the phenomenon of School WhatsApp groups, which is a part of the school life but cannot be fully controlled, is a new communication field and presents a complex structure, has been examined within the scope of phenomenology design.

\section{Study Group}

Criterion sampling method, which is one of the purposeful sampling methods was employed in determining the participants of the study group. In the criterion sampling, individuals, events or situations whose specific characteristics are taken into consideration are used to form the sample or the study group depending on the purpose of the study (Buyukozturk, at al., 2010). In this research, the participants' being located in the city center of Sivas, selected from schools located in different socio-economic regions and voluntary participation have been determined as criteria for participants. According to this, 15 schools with low socioeconomic level and 15 schools with high socio-economic level were selected and this study was applied to teachers and administrators who volunteered in these schools. In this study, data from 110 teachers and 51 managers were evaluated.

\section{Data Collection Tool}

The data of the research was collected through a questionnaire developed by the researcher. The questionnaire development process consists of four stages. These are, respectively, defining the problem, writing the items, asking experts' opinions about the questionnaire, and pilot study (Anderson, 1990; As cited in: Buyukozturk, 2005). During the stage in which the 
problem was defined, face-to-face interviews were conducted with 6 teachers from 3 different schools about School WhatsApp groups and evaluations were made on the positive and negative effects of these groups and the reflections of them on education and training. In the light of these interviews, a research problem has emerged about the need to use the School WhatsApp groups correctly and what these usage types should be. In the second stage, the items that would be included in the questionnaire were determined again following the interviews made with the teachers. In the third stage, the questionnaire items were shared with 3 academic members who are experts in their field and their opinions were taken. In addition, 2 Turkish teachers evaluated the questionnaire in terms of comprehensibility and grammar. After the questionnaire took its final form, the application was performed on 5 teachers who are not a part of the study group and the questionnaire was finalized according to the feedback. Accordingly, the questionnaire included 3 open-ended questions after the explanation sections. Questions in the questionnaire: a) What are the positive aspects of teacher-parent WhatsApp groups? b) What are the negative aspects of teacher-parent WhatsApp groups? c) What are your suggestions for the use of teacher-parent WhatsApp groups?

\section{Data Analysis}

The data obtained from the research were evaluated by content analysis method which is one of the most used analysis methods in qualitative research. Through the content analysis, the aim was to encode the data and reach categories and themes through codes (Yildirim and Simsek, 2011). Content analysis steps can be expressed as $a$. for classification of indicators and, $b$. revealing which judgments these indicators contain, $c$. in the light of clearly formulated rules, $d$. evaluation of propositions put forward by the researcher as a scientific report (Janis, 1949:425; As cited in: Kocak and Arun, 2006:22). In this context, the data were coded by two researchers to provide consensus and the categories and themes were reached. Tables were prepared and explanations were made through these tables in order to provide a more comprehensible presentation of the classifications reached. In order to support the explanations made, direct quotations were included. Participants who are teachers (T1, T2, T3, $\mathrm{T} 4 \ldots \ldots .$.$) and who are administrators \left(\mathrm{A}_{1}, \mathrm{~A}_{2}, \mathrm{~A}_{3}, \mathrm{~A}_{4} \ldots \ldots ..\right)$ were given the nicknames for demonstration within the text.

In the research, the concepts of credibility, transmissibility, consistency and confirmability were used instead of validity and reliability concepts (Mills, 2003). In this context, each stage of the research was presented in detail. In the development of the data collection tool, the opinions of the teachers who work in the field and experience the WhatsApp phenomenon directly have been utilized, and it was finalized with expert opinions and sample applications. During the data collection process, all participants were informed about the aim of the research and each participant was identified with nicknames in order to prevent data loss, $90 \%$ consensus was reached through the coding of the collected data by two researchers. During the research process, the researcher acted objectively and presented the data with direct quotations in the text.

\section{FINDINGS}

Findings related to school WhatsApp groups were structured under 3 themes: teachers' opinions on teacher-parent WhatsApp groups; administrators' opinions on teacher-parent 
WhatsApp groups; teachers' and administrators' suggestions on teacher-parent WhatsApp groups.

\section{Teachers' opinions on teacher-parent WhatsApp groups:}

Teachers' opinions on teacher-parent WhatsApp groups were presented in the same table as positive and negative opinions. Positive opinions, structured with 3 categories consisting a total of 163 codes, which may be counted as instant communication, social relations and recognition of student; negative opinions, structured with 4 categories consisting of a total of 226 codes which may be counted as reflections on the teacher, virtual communication and addiction of students are presented in Table 1.

Table 1. Teachers' opinions on teacher-parent WhatsApp group

\begin{tabular}{|c|c|c|}
\hline \multicolumn{3}{|c|}{ Categories $\quad$ Codes } \\
\hline \multicolumn{2}{|l|}{ Positive aspects: } & $f$ \\
\hline \multirow{3}{*}{$\begin{array}{l}\text { Instant } \\
\text { Communication }\end{array}$} & Teachers being able to make announcements more easily and quickly & 72 \\
\hline & $\begin{array}{l}\text { The ability to transfer the work requested from the parent to all } \\
\text { parents with one message }\end{array}$ & 12 \\
\hline & Saving time & 12 \\
\hline \multirow[t]{3}{*}{ Social relations } & Bonding of parents with each other & 10 \\
\hline & Contribution to the collaboration between school and family & 12 \\
\hline & Sharing the work done at school & 20 \\
\hline \multirow{2}{*}{$\begin{array}{l}\text { Recognition of } \\
\text { student }\end{array}$} & Solving student problems more quickly & 15 \\
\hline & Keeping track of student development & 10 \\
\hline \multicolumn{2}{|l|}{ Total } & 163 \\
\hline \multicolumn{3}{|l|}{ Negative Aspects: } \\
\hline \multirow{2}{*}{$\begin{array}{l}\text { Reflections on } \\
\text { the teacher }\end{array}$} & Violation of the teacher's private life & 22 \\
\hline & Parents telling the teacher what they need to do & 20 \\
\hline \multirow[t]{4}{*}{$\begin{array}{l}\text { Damaging the } \\
\text { relationships }\end{array}$} & $\begin{array}{l}\text { That unnecessary sharing of any related or unrelated topic spoils the } \\
\text { relationships }\end{array}$ & 66 \\
\hline & Frequent conflicts due to misunderstandings & 34 \\
\hline & Some sharings' being reflected on students, occurrence of problems & 12 \\
\hline & $\begin{array}{l}\text { Turning the private situations experienced in the classroom into } \\
\text { matters of debate }\end{array}$ & 10 \\
\hline \multirow{2}{*}{$\begin{array}{l}\text { Virtual } \\
\text { communication }\end{array}$} & Parents trying to solve every problem via WhatsApp & 16 \\
\hline & Declining face-to-face communication with the teacher & 18 \\
\hline \multirow{2}{*}{$\begin{array}{l}\text { Student } \\
\text { addiction }\end{array}$} & Reducing students' sense of responsibility & 17 \\
\hline & Students trying to get all kinds of information via WhatsApp & 11 \\
\hline \multicolumn{2}{|l|}{ Total } & 226 \\
\hline
\end{tabular}

Source: Authors

When teachers' opinions on teacher-parent WhatsApp groups are examined, it is seen that negative opinions are predominant. In this regard, the category of damaging relationships comes to the fore, and misunderstandings, unnecessary sharings, negative situations reflected on students, and private situations in the classroom were emphasized. In addition, the teacher not having a private life and the decrease in the students' sense of responsibility are among the remarkable findings. In the positive opinions, easy and instant communication, 
sharing the work done at school and solving the student problems more quickly come to the fore. Some teachers' opinions on the subject are presented directly below:

The positive aspects of it are accessing parents at the same time, making notifications about the lessons and children, and facilitating the making of announcements (T5).

They are very nice in terms of quick decision-making, time saving, quickly accessing to more than one person, making announcements (T15).

The most negative aspect is that rumors and gossips spread at least as fast as the right information. Unnecessary conversations appear. And a subject that can be discussed directly with the teacher or another parent occupies the group unnecessarily (T75).

\section{Administrators' opinions on teacher-parent WhatsApp groups:}

Administrators' opinions on teacher-parent WhatsApp groups were presented as positive and negative opinions within the same table. Positive opinions, structured with 3 categories consisting a total of 134 codes of instant communication, keeping track of the student and collaboration; negative opinions, structured in 3 categories, consisting a total of 158 codes of reflections on parents, reflections on students and reflections on teachers are presented in Table 2.

Table 2. Administrators' opinions on teacher-parent WhatsApp groups

\begin{tabular}{|c|c|c|}
\hline Categories & Codes & \\
\hline \multicolumn{3}{|l|}{ Positive aspects: $\mathrm{f}$} \\
\hline \multirow{3}{*}{$\begin{array}{l}\text { Instant } \\
\text { Communication }\end{array}$} & Providing faster information transfer about students and school & 44 \\
\hline & Collective access to all parents & 18 \\
\hline & Saving time & 14 \\
\hline \multirow[t]{2}{*}{$\begin{array}{l}\text { Keeping track of } \\
\text { students }\end{array}$} & $\begin{array}{l}\text { Being an area where student activities are done in the school can be } \\
\text { shared }\end{array}$ & 17 \\
\hline & Keeping track of the student closely & 17 \\
\hline \multirow[t]{2}{*}{ Collaboration } & Ensuring collaboration between parents & 13 \\
\hline & Ensuring teacher-parent collaboration & 11 \\
\hline Total & & 134 \\
\hline \multicolumn{3}{|l|}{ Negative Aspects: } \\
\hline \multirow{3}{*}{$\begin{array}{l}\text { Reflections on } \\
\text { parents }\end{array}$} & Out of purpose, unnecessary messaging between parents & 35 \\
\hline & Discussions between parents & 24 \\
\hline & Reducing the rate of parents coming to school & 15 \\
\hline \multirow{2}{*}{$\begin{array}{l}\text { Reflections on } \\
\text { student }\end{array}$} & Students accessing information and exploitation of it & 12 \\
\hline & Reducing the sense of responsibility of the student & 10 \\
\hline \multirow{3}{*}{$\begin{array}{l}\text { Reflections on } \\
\text { the teacher }\end{array}$} & Usage out of working hours & 24 \\
\hline & Parents trying to control and direct the teacher & 20 \\
\hline & Damaging the relationship between teachers and parents & 18 \\
\hline Total & & 158 \\
\hline
\end{tabular}

Source: Authors

When administrators' opinions on teacher-parent WhatsApp groups are examined, it is seen that negative opinions are predominant. It was determined that, in the 3 categories of negative opinions, negative reflections on the teacher and the parents were more than negative reflections on students. Out of purpose messaging among the parents, students accessing information and usage during out of working hours come to the fore. In positive views, instant communication was the most emphasized category, this was followed by keeping track of students and collaboration categories, respectively. In positive opinions, the fast information transfer about the students and the school, the sharing of activities held in 
the school, and the increased collaboration among the parents come to the fore. Some administrators' opinions on the subject are presented directly below:

It is undoubtedly beneficial for teachers and parents to be in constant communication. While continuous follow-up and feedback for keeping track of the students are provided from involved parents, unfortunately, with careless parents one-way communication is established (A2).

Negative aspects, such as texting during lesson hours, sharing information about other than students and education. Sharing information that will hurt the personality characteristics (A18).

Even though the groups that were established for parents are useful at first, later the situation gets out of hand and it starts to be completely problematic. The lack of gestures and facial expressions in correspondences causes misunderstandings. Even if the comments are good, misunderstandings or jealousy appear (A38).

\section{Teachers' and administrators' suggestions on teacher-parent WhatsApp groups:}

Teachers' and administrators' suggestions on teacher-parent WhatsApp groups are presented separately within the same table. Teachers' suggestions structured with 2 categories consisting of a total of 63 codes of group rules and face-to-face communication; administrators' suggestions structured with 3 categories consisting of a total of 55 codes are presented in Table 3.

Table 3: Teachers' and administrators' suggestions on teacher-parent Whatsapp groups

\begin{tabular}{|c|c|c|}
\hline Categories & Codes & \\
\hline \multicolumn{2}{|c|}{ Teacher suggestions: } & $f$ \\
\hline \multirow{6}{*}{ Group rules } & Teachers should form the group & 5 \\
\hline & Only admins should write & 6 \\
\hline & Parents should be answered privately not in the group & 5 \\
\hline & The teacher should share general topics and use them for guidance. & 7 \\
\hline & Group rules should be set and compliance with them should be ensured & 9 \\
\hline & Individual status of students should not be written to the group & 13 \\
\hline \multirow{2}{*}{$\begin{array}{l}\text { Face-to-face } \\
\text { communication }\end{array}$} & One-on-one interviews will be more useful & 10 \\
\hline & Parental meetings are more useful than parent groups & 8 \\
\hline Total & & 63 \\
\hline \multicolumn{3}{|c|}{ Administrator Suggestions: } \\
\hline \multirow{3}{*}{$\begin{array}{l}\text { Face-to-face } \\
\text { communication }\end{array}$} & Such talks must be made face to face & 8 \\
\hline & The student should see his/her parents at school. & 6 \\
\hline & Parents should communicate within the school actively. & 4 \\
\hline \multirow{2}{*}{ Bulk message } & Parents should be informed via bulk message & 6 \\
\hline & Sending SMS as the school instead of WhatsApp & 5 \\
\hline \multirow{4}{*}{ Group rules } & Group members should be informed about the purposes of the group & 11 \\
\hline & $\begin{array}{l}\text { It should be stated clearly from the start that the group rules are to be } \\
\text { applied }\end{array}$ & 6 \\
\hline & $\begin{array}{l}\text { The group should be established with common decisions on specific issues } \\
\text { and purposes. }\end{array}$ & 6 \\
\hline & Should be officialized or an alternative program should be developed & 3 \\
\hline Total & & 55 \\
\hline
\end{tabular}

Source: Authors

On teacher-parent WhatsApp groups, teachers and administrators have similarly emphasized the group rules and face-to-face communication. Group rules can be summarized as only admins writing in the group, shares on general issues, providing adequate information about 
the purpose of the group and ensuring compliance with rules. Opinions about one-to-one interviews being more beneficial when it comes to face-to-face communication, that the student should see his / her parent at school and about parent meetings were expressed. In addition, administrators emphasized alternative methods to reach parents. Some teachers' and administrators' opinions on the subject are presented directly below:

I suggest that the WhatsApp group admin should be the teacher and that only the teacher make shares in the group, and the message section should be unavailable to parents ( $(\mathrm{T} 12)$.

Groups in which the teacher is not included (message is sent to one parent and they share it with the other group) should be established again within the framework of certain rules (T46).

Parent groups are more tricky than teacher groups. Teacher, group admin, should be more careful in every aspect (A6).

\section{CONCLUSION AND DISCUSSION}

When teachers' and administrators' positive opinions on teacher-parent WhatsApp groups were analyzed, it was seen that teachers' opinions were structured within instant communication social relations and recognition of student and administrators' opinions were structured within instant communication, keeping track of the student and collaboration. In both of the participant groups, instant communication comes to the fore. It can be said that instant transmission of problems experienced or activities are done in the school environment increased the teacher-parent interaction, and this situation made the need for instant communication indispensable. According to the participants' views, Teacher-parent WhatsApp groups also facilitate student follow-up and increase interaction between teacher and parent. There are many studies in the literature that emphasize the importance of teacher-parent communication (Hornby and Witte, 2010; Ankrum, 2016; Mestry and Grobler, 2007; Bayrakdar and Yigit, 2006; (eylan and Akar, 2010; Caliskan and Ayik, 2015). However, there are few studies on teacher-parent WhatsApp groups in the literature. Balci and Sahin (2018) examined teacher-parent WhatsApp groups among preschool teachers and parents. According to the research findings, WhatsApp group is used for the purposes of making announcements, sharing photos / videos of activities done inside and outside of the class and sending newsletters and this increases communication between families. Mayangsari and Aprianti (2017) state that In teacher-parent WhatsApp group, information about student permits, celebrations, class activities and education are shared and this contributes to the quality of the school. Wasserman and Zwebner (2017) concluded that in teacher-parent WhatsApp group, the technical issues and the subjects needed for the course were shared and this is useful for teachers to continue their work efficiently. The results of this research coincide with the results of researchs in the literature.

When teachers' and administrators' negative opinions on teacher-parent WhatsApp groups are analyzed, teachers' opinions were structured within reflections on the teacher, damaging relationships, virtual communication and addiction of students categories and administrators' opinions were structured within reflections on parents, reflections on students and reflections on teachers categories. While damaging relationships come to the forefront in teachers' opinions, reflections on parents come to the fore in administrators' opinions. Teachers and administrators have more negative opinions about teacher-parent WhatsApp groups than they have positive opinions. Especially unnecessary shares in all relevant unrelated matters, damages the relationships, conflicts due to misunderstandings happen frequently, teacher's private life is violated, sense of responsibility of students decreases and these situations negatively affect the teacher-parent relationship. In Balci and Sahin, (2018)'s research, 16 
teachers out of 29 teachers who participated in the study stated that they had problems in teacher-parent WhatsApp group. In addition, 25 of them expressed that teacher-parent WhatsApp groups have disadvantages. These problems are listed as discussions between families in the group, misuse, correspondence on private topics, comparison of children, misunderstanding. Wasserman and Zwebner (2017), in their research, stated that teacherparent WhatsApp groups were exploited, misused, parents tried to establish superiority over each other, students avoided responsibility by learning their homework through WhatsApp; Mayangsari and Aprianti (2017) stated that some parents with lack of media literacy manipulated the group, all kinds of information were shared without thinking, and a chaos environment was formed where the main issue was strayed because of information pollution. The literature findings support the results of this study.

On teacher-parent WhatsApp groups, teachers and administrators have similarly emphasized the group rules and face-to-face communication. Group rules can be summarized as only admins writing in the group, shares on general issues, providing adequate information about the purpose of the group and ensuring compliance with rules. Opinions about one-to-one interviews being more beneficial when it comes to face-to-face communication, that the student should see his / her parent at school and about parent meetings were expressed. In addition, administrators emphasized alternative methods to reach parents. Balci and Sahin, (2018) point out that important issues should be discussed face to face, the purpose of the group and how it should be used should be explained, and use of alternative communication tools is required; Mayangsari and Aprianti (2017) state that the level of media literacy of parents using WhatsApp should be increased; Wasserman and Zwebner (2017) state that rules and boundaries should be clearly defined in WhatsApp groups. The literature, in addition to the researches carried out about school WhatsApp groups, includes suggestions on the use of social media in general. It can be said that these suggestions are valid for the school WhatsApp groups, as well. Erkek (2016) suggests that organization staff should pay attention to the language they use on social media environment and their shares, keep their seriousness and courteousness consciously; Tanriverdi and Sagir (2014) believe that social media should be used consciously; Sarsar, Basbay and Basbay (2015) recommend that both teachers and planners should recognize social media opportunities and use them to support and enrich education; Akar (2016), suggests that especially education administrators should develop strategies that would ensure means-ends balance in the use of internet and promote conscious use of it.

It is frequently stated in literature that healthy organizational communication contributes to the development and evolution of the school and that organization communication is to be realized effectively for a happy and peaceful school environment (Schad, 2019; De Nobile, 2017; Lijuan and Hallinger, 2016; Ekici, 2012; Alakurt and Yilmaz, 2016). Researches on WhatsApp groups that are established with educational purposes in the school and have different group characteristics and how these WhatsApp groups contribute to the education process are mostly encountered in the literature. It has been concluded that WhatsApp groups established with students form a platform that Susanti and Tarmuji (2016) facilitate English language learning, Naidoo and Kopung (2016) increase mathematics performance of students, Yaman (2016) increase academic success in Arabic language learning, Sebetci, et al. (2018) ensuring positive interaction between students on education and learning, Yee, Abdullah and Nawi (2016), contribute to learning and education experience of teacher candidates in teaching practicing lesson, Annamalia (2018) provides support for teacher candidates' growth. Rosenberg and Asterhan (2018) state that WhatsApp group established 
between the teacher and students coupled with the teacher being a role model affects lesson follow up of students and student behaviors positively. Cansoy (2017), in his research, concluded that in the WhatsApp group established between physics, chemistry and biology teachers, sharings which are vocational and related the school contribute to the vocational development of teachers.

School WhatsApp groups with its positive and negative aspects have become one of the indispensable communication tools of the school organization. However, it should be ensured that WhatsApp groups do not become the only means of communication in the school, faceto-face communication shouldn't be abandoned, certain rules should be followed in WhatsApp use, WhatsApp use should be analyzed periodically according to certain criteria, intense use of WhatsApp shouldn't interrupt actual work, WhatsApp should serve a productive school environment rather than confusion and chaos.

\section{REFERENCES}

Addi-Raccah, A., \& Yemini, M. (2018). What is up? Parental Whatsapp discussion groups in diverse educational settings in Israel, Multicultural Education Review, 10(4), 310-326.

Akar, E. (2010). Sanaltoplu lukların birturuolar aksosyal agsiteleri - Bir pazarlam ailetisimi kanaliolar akisleyisi, Anadolu Universitesi Sosyal Bilimler Dergisi,10(1), 107-122.3.

Akar, F. (2016) Ergenlerin internet vesosyal medya kullani mozel likleriil internet kullanim amaclarin incesitli degisken lercein celenmesi (Yozgatlli Ornegi). Uluslararasi Bozoksempozyumu, Yozgat.

Alakurt, T. ve Yilmaz, R. (2016). Universite ogrencilerin in facebook gruplarin dakibil gipaylasma davranislar ininin celenmesi. In 10th International Computer and Instructional Technologies Symposium (ICITS), 81-91.

Alican, C. (2013). Ortaokulvelise de ogrenim goreno grencilerin sosyal medya kullanimin ailiskint utumlari: Urgupornegi, Erciyes Universitesi Sosyal Bilimler Enstitusu Dergisi, 1(35), 1-14.

Ankrum, R. J. (2016). Socioeconomic status and its effect on teacher/parental communication in schools, Journal of Education and Learning, 5(1), 167-175.

Annamalai, N. (2018). How do we know what is happening in WhatsApp: A case study investigating pre-service teachers' online activity, Malaysian Journal of Learning and Instruction, 15(2), 207-225.

Arlestig, H. (2007). Principals' communication inside schools: A contribution to school improvement? InThe Educational Forum, 71, (3), 262-273.

Balci, A. veSahin, F. T. (2018). Ogretmen-aileiletisimindewhatsappuygulamasininkullanimi, GEFAD / GUJGEF 38(2), 751-778.

Bansal, T., \& Joshi, D. (2014). A study of students experiences of WhatsApp mobile learning, Global Journal of Human-Social Science Research, 14(4), 26-33.

Bayrakdar, M. veYigit, B. (2006). Okul-cevreiliskileri. Ankara: Pegem A.

Bicer, S. (2014). Akademisy enlerin sosyal aglar dabulunma motivasyonlari: Facebook ornegi. Dumlupınar Universitesi Sosyal Bilimler Dergisi, (40), 59-80.

Bouhnik, D., Deshen, M., \& Gan, R. (2014). WhatsApp goes to school: Mobile instant messaging between teachers and students, Journal of Information Technology Education: Research, 13(1), 217-231.

Boyd, D. M. \& Elisson, N. B. (2007). Social network sites: Definition, history, and scholarship, Journal of Computer-Mediated Communication, 1(13), 210-230.

Bursalıoglu, Z. (2005). Okuly onetiminde yeniyapi ve davraniş. Ankara: Pegem A 
Buyukozturk, S. (2005). Anket gelistirme,Turk Egitim Bilimleri Dergisi, 3(2), 133-151.

Buyukozturk, S., Cakmak, E.K., Akgun, O.E., Karadeniz, S. ve Demirel, F. (2010) Bilimsel Arastırma Yontemleri. Ankara: Pegem A.

Bynum, S. L. (2011). Utilizing Social Media to Increase Student Engagement: A Study of Kern County Public Schools. (Unpublished Thesis). Department of Public Policy and Administration, California State University.

Caliskan, N. ve Ayik, A. (2015). Okul aile birligi ve velilerle iletisim,Ahi Evran Universitesi Sosyal Bilimler Enstitusu Dergisi, 1(2), 69-82.

Cansoy, R. (2017). Teachers' professional development: The case of WhatsApp, Journal of Education and Learning, 6(4), 285-293.

Celep, C. (1992). Ilkokullar dayonetici-ogret meniletisimi, Hacettepe Universitesi Egitim Fakultesi Dergisi, 8(8), 301-316.

Cemaloglu, N. veBicak, D. K. (2015). Sosyal aglar daogretmen-ogrenci arkadasli ginayonelik ogrencialgilari, Turk Egitim Bilimleri Dergisi, 13(2), 51-76.

Cemrek, F., Baykus, H., \&Ozaydin, O. (2014). Sosyal medya kullanim vedavrani slarin inkullanımlar vedoy umlary aklasimi baglamin dain celenmesi: Eskisehir Osmangazi Universitesiornegi, Alphanumeric Journal, 2(2), 61-76.

Ceylan, M. ve Akar, B. (2010). Evaluation of teachers' and parents' views on schoolfamily cooperation in high schools (Karacasu High School given as example), Çankırı Karatekin University Journal of Institute Social Sciences, 2, 43-64.

Cox, D., \& McLeod, S. (2014). Social media marketing and communications strategies for school superintendents, Journal of Educational Administration, 52(6), 850-868.

Dabbagh, N., \& Kitsantas, A. (2012). Personal learning environments, social media, and selfregulated learning: A natural formula for connecting formal and informal learning. The Internet and higher education, 15(1), 3-8.

De Nobile, J. (2017). Organisational communication and its relationships with job satisfaction and organisational commitment of primary school staff in Western Australia, Educational Psychology, 37(3), 380-398.

Ekici, M. (2012). Sosyal aglarin egitim baglamin dakullanimi, Usak Universitesi Sosyal Bilimler Dergisi, (10), 156-167.

Eren, V. ve Aydin, A. (2014). Sosyal medyanin kamuoyu olusturmadaki rolu ve muhtemel riskler, KMU Sosyal ve Ekonomik Arastırmalar Dergisi, 16 (Ozel Sayi I), 197-205.

Erkek, S. (2016). Kamu kurumlarinda sosyal medya kullanimi: Saglik bakanligiornegi, Selcuk Universitesi Sosyal Bilimler Enstitusu Dergisi, (35), 141-150.

Farmer, M. Y., Liu, A., \& Dotson, M. (2016). Mobile phone applications (WhatsApp) facilitate communication among student health volunteers in Kenya. Journal of Adolescent Health, 58(2), 54-55.

Genc, N. (2009). Yonetimve organizasyon. Ankara: Seckin Yayincilik.

Gon, S., \&Rawekar, A. (2017). Effectivity of e-learning through WhatsApp as a Teaching Learning Tool, MVP Journal of Medical Science, 4(1), 19-25.

Greenhow, C., \& Robelia, B. (2009). Old communication, new literacies: Social network sites as social learning resources, Journal of Computer-Mediated Communication, 14(4), 11301161.

Hershkovitz, A., Abu Elhija, M., \& Zedan, D. (2019). WhatsApp is the message: Out-of-class communication, student-teacher relationship, and classroom environment, Journal of Information Technology Education: Research, 18, 63-95.

Hornby, G., \& Witte, C. (2010). Parent Involvement in Inclusive Primary Schools in New Zealand: Implications for Improving Practice and for Teacher Education, International Journal of Whole Schooling, 6(1), 27-38. 
Ibrahim, A., \& Mahmoud, S. (2017). Principals' Communication Styles and School Performance in Al Ain Government Schools, UAE, International Journal of Research Studies in Education, 6(1), 29-46.

Ilgar, L. (2005). Egitimyonet imiokulyon etimis inifyonetimi. Istanbul: Beta Basim.

Jafari, S., \& Chalak, A. (2016). The role of WhatsApp in teaching vocabulary to Iranian EFL learners at junior high school, English Language Teaching, 9(8), 85-92.

Karsli, M. D. (2006). Etkili Okul Yoneticiligi. Istanbul: Morpa Kultur Yayinlari Ltd Sti.,

Kocabiyik, O. O. (2016). Olgubilim vegomulukuram: Baziozellik leracisindan karsilastirma, Trakya Universitesi Egitim Fakultesi Dergisi, 6(1), 55-66.

Kocadere, S. A., \& Askar, P. (2013). Contributions and usage frequencies of social media tools: Teaching practice example, Elementary Education Online, 12(4), 1120-1132.

Kocak, A. ve Arun, O. (2006). Icerik analizi calismalarinda orneklem sorunu, Selcuklletisim, 4(3), 21-28.

Koseoglu, O. (2012). Sosyal agsitesi kullanicilarinin motivasyonlari: Facebook uzerin ebirarastırma, Selcuk Universitesilletisim Fakultesi Akademik Dergisi, 7(2), 58-81.

Koseoglu, Y. ve Al, H. (2013). Bir siyasal propaganda araciolarak sosyalmedya. Akademik Incelemeler Dergisi (AID), 8(3), 103-125.

Lenhart, A., Purcell, K., Smith, A., \&Zickuhr, K. (2010). Social Media \& Mobile Internet Use among Teens and Young Adults. Millennials. Pew internet \& American life project.

Lester, D. A. (2012). Social media: Changing advertising education, Online Journal of Communication \& Media Technologies, 2(1), 116-25.

Lijuan, L., \& Hallinger, P. (2016). Communication as a mediator between principal leadership and teacher professional learning in Hong Kong primary schools, International Journal of Educational Reform, 25(2), 192-212.

Liu, Y. (2010). Social media tools as a learning resource, Journal of Educational Technology Development and Exchange (JETDE), 3(1), 101-114.

Mayangsari, I. D., \& Aprianti, A. (2017). Understanding communication among parents and teachers in WhatsApp. Case study in Bandung, Indonesia, Malaysian Journal of Social Sciences and Humanities (MJSSH), 2(2), 19-24.

Mestry, R., \& Grobler, B. (2007). Collaboration and communication as effective strategies for parent involvement in public schools, Educational research and reviews, 2(7), 176-185.

Mills, G. E. (2003). Action research a guide for the teacher researcher (2nd. edition). Pearson Education, Boston.

Mumby, D. K., \& Kuhn, T. R. (2018). Organizational Communication: A Critical Introduction. London: Sage Publications.

Murray, C. (2008). Schools and social networking: Fear or education. Synergy Perspectives: Local, 6(1), 8-12.

Naidoo, J., \& Kopung, K. J. (2016). Exploring the use of WhatsApp in mathematics learning: A case study, Journal of Communication, 7(2), 266-273.

Oyman, N. (2016). Sosyal medya dindarligi. Kahramanmaras Sutculmam Universitesillahiyat Fakultesi Dergisi, (28), 125-167.

Ozdemir, S. (2000). Egitim deorgut selyenilesme. Ankara: Pegem.

Ozdemir, S. ve Erdem, R. (2016). Sosyal medyanin orgut ici iletisimdeki rolu. ManasSosyalArastırmalarDergisi, 5(3), 247-270.

Pinar, Y. ve Pinar N. K. (2017). Universite ogrencilerinin whatsapp metin yazismalari ve emoji kullanim tutumlari.Idil, 6 (38), 2709-2719.

Rosenberg, H., \& Asterhan, C. S. (2018). "WhatsApp, teacher?" - student perspectives on teacher-student whatsapp interactions in secondary schools, Journal of Information Technology Education: Research, 17, 205-226. 
Sahan, O., Coban, M. veRazi, S. (2016). Ingiliz cedeyimlerin WhatsApp araciligi ylaogretimi: Akilli telefonlarin sinif disikullanimi, Erzincan Universitesi Egitim Fakultesi Dergisi, 18(2), 1230-1251.

Sarsar, F., Basbay, M., \& Basbay, A. (2015). Ogrenme-ogret mesurecinde sosyalmedy akullanimi, Mersin Universitesi Egitim Fakultesi Dergisi, 11(2), 418-431.

Schad, E. (2019). No time to talk! Teachers' perceptions of organizational communication: Context and climate, Educational Management Administration \& Leadership, 47(3), 421-442.

Sebetci, O., Topal, A., Hanayli, M. C. veDonuk, G. G. (2018). Perceptions of university students on whatsapp in educational settings, Route Educational and Social Science Journal, $5(6), 63-76$.

Sener, E. ve Samur, M. (2013). Sagligi gelistirici bir unsur olarak sosyal medya: Facebookta saglık,Gumushane Universitesi Saglık Bilimleri Dergisi, 2(4), 508-523.

Sengoz, A. ve Eroglu, E. (2017). Orgutlerde sosyal medya kullanimi: sosyal medya algilari, amaclari ve kullanim aliskanliklari, Gumushane Universitesi Iletisim Fakultesi Elektronik Dergisi, 5(1), 503-524.

Solmaz, B., Tekin, G., Herzem, Z. ve Demir, M. (2013). Internet ve sosyal medya kullanimiuzerine bir uygulama, Selcuklletisim, 7(4), 23-32.

Susanti, A., \& Tarmuji, A. (2016). Techniques of optimizing WhatsApp as an instructional tool for teaching EFL writing in Indonesian senior high schools, International Journal on Studies in English Language and Literature (IJSELL), 4(10), 26-31.

Tanriverdi, H. ve Sagir, S. (2014). Lise ogrencilerinin sosyal ag kullanim amaclarinin ve sosyal aglari benimseme duzeylerinin ogrenci basarisina etkisi, Adiyaman Universitesi Sosyal Bilimler Enstitusu Dergisi, (18), 775-822.

Tarisayi, K. S., \& Manhibi, R. (2017). Social media tools in education: A case of WhatsApp use by heritage studies teachers in Zimbabwe, Greener Journal of Social Sciences, 7 (4), 34-40.

Taymaz, H. (2009). Okulyonetimi. Ankara: Pegem A Yayincilik.

Thompson, B. (2009). Parent-teacher e-mail strategies at the elementary and secondary levels, Qualitive Research Reports in Communication, 10(1), 17-25.

Timmerman, C. E., \& Salem, P. J. (2017). Organizational communication traditions, transitions and transformations, Management Communication Quarterly, 31(1), 113-115.

Vander Broek, K. S., Puiszis, S. M., \& Brown, E. D. (2009). Schools and social media: first amendment issues arising from student use of the internet, Intellectual Property \& Technology Law Journal, 21(4), 11-27.

Wasserman, E., \& Zwebner, Y. (2017). Communication between teachers and parents using the WhatsApp application, International Journal of Learning, Teaching and Educational Research, 16(12), 1-12.

Yaman, G. S. (2016). Yabanci dilolarak arapca ogretiminde whatsapp kullanimi. Uluslararasi Guncel Egitim Arastirmalari Dergisi, 2(1), 37-47.

Yee, B. C., Abdullah, T., \&Nawi, A. M. (2016). Supporting and Improving Reflective Practice among Pre-Service Teachers through WhatsAPP, Jurnal Pendidikan Nusantara. Special Edition, 53-72.

Yildirim, A. veŞimsek, H. (2011). Sosyal bilimlerde nitel arastırma yontemleri. (8. Baski). Ankara: Seckin. 


\section{Biographical notes:}

Soner DOĞAN is an Associate Professor in Education Faculty of Sivas Cumhuriyet University, Sivas, Turkey. His research interests include leadership, school climate, conflict management, and school vandalism. 